\title{
Combined Effect of Personality Factors and Cognitive Factors on Students' Self-Employment Intentions in Technical, Vocational Education and Training in Kenya
}

\author{
Kahando David Maina, Mungai Esther Nyambura \\ Department of Entrepreneurship and Technology Management, School of Business and Management Studies, The Technical University of \\ Kenya, Nairobi, Kenya
}

Email address:

davidkahando@gmail.com (K. D. Maina), estherthukuagmail.com (M. E. Nyambura)

\section{To cite this article:}

Kahando David Maina, Mungai Esther Nyambura. Combined Effect of Personality Factors and Cognitive Factors on Students' SelfEmployment Intentions in Technical, Vocational Education and Training in Kenya. International Journal of Business and Economics Research. Vol. 8, No. 3, 2019, pp. 133-141. doi: 10.11648/j.ijber.20190803.17

Received: May 8, 2019; Accepted: June 11, 2019; Published: June 19, 2019

\begin{abstract}
Entrepreneurship has been acknowledged as a key driver of economic growth across many economies both in developed and developing countries. Entrepreneurial intention has been empirically proved to be the predictor of entrepreneurial behaviour. This study used personality factors (need for accomplishment and internal locus of control) and cognitive Factors (personal attraction and perceived social valuation) to assess their combined effect on self-employment intentions in Technical, Vocational Education and Training in Kenya. The study objective was to establish the combined effect on the relationship between personality factors and cognitive factors on students' self-employment intentions. A crosssectional survey research design was used to obtain quantitative data. A structured questionnaire was developed and administered to diploma engineering finalist students sampled from 41 public TVET Institutions in Kenya between 2016 and 2017. The data was analysed using both descriptive statistics and inferential statistics. Pearson's Coefficient Correlation was used to examine the relationship between independent variables and the dependent variable. Factor analysis was conducted to investigate the internal structure among the set of variables. Multiple regressions analysis was used to examine the effect of independent variables on the dependent variable. The findings indicated that there was a positive and significant relationship between combined effect of personality factors and cognitive factors on self-employment intention. Consequently, the combined effect of independent variables strongly influences dependent variable. The study concluded that although personality factors and cognitive factors positively individually influenced self-employment intention, combined association enhanced this effect further among engineering students in TVET institutions in Kenya.
\end{abstract}

Keywords: Personality Factors, Combined Effect, Congnitive Factors, Entrepreneurship, Self-Employment Interntion

\section{Introduction}

Entrepreneurship has recently been acknowledged as a key driver of economic growth across many economies both in developed and developing countries. In addition, the emergence of new and innovative business start-ups has positively impacted economic growth of nations globally. Many countries have embraced entrepreneurial activities as a primary stream of rejuvenating their economy, a recipe to cope with unemployment problems, and job creation in most developing countries. In Kenya, the past few decades, massive unemployment from universities and tertiary institutions, and lack of affirmative action to eradicate unemployment for the Kenyan youth have raised major concerns among policy makers and entrepreneurs. Hence the introduction of Technical and vocational and training (TVET) courses.

TVET remains a key development strategy for international development agencies and governments [1-2]. UNESCO report [1] defined TVET as all forms and levels of the educational process involving in addition to general knowledge, the study of technologies and related sciences and the acquisition of practical skills, know-how, attitudes and understanding relating to occupations in various sectors 
of economic and social life. In Kenya, TVET is part of the education and training system placed under Directorate of Technical Vocational and Training (DTVET) within the Ministry of Education, Science and Technology (MoEST) targeting fresh graduates from secondary schools. According to Kenya's economic survey 2018, the number of public TVET institutions stood at 985; one Technical Teachers College; 11 National Polytechnics; 850 technical and vocational centres; 123 technical and vocational colleges (TVC. The report from the Economic Survey indicated that, TVET enrolment declined by 7.7 per cent from 564,507 in $2016 / 17$ to 520,893 in $2017 / 18$. The decline in enrolment was mainly occasioned by reduction in the number of candidates who met the minimum university entry requirements.

Many scholars, [3-6] have realized that targeting postsecondary students mean that the future of self-employment lies with graduate entrepreneurs who are expected to contribute to the economy of any country. Furthermore, this cadre of students are unlikely to have any or substantial prior business experiences as all of them are admitted directly after secondary school. Targeting this cadre of students therefore agree to the investigation of self-employment intention before the actual self-employment. The government's objective in emphasizing the importance of competence based skills in TVET institutions is therefore in line with the expected outcome.

The employability of TVET graduates and their ability to start new businesses and employ other Kenyans while contributing to the country's economic wellbeing are central to the mission of the Kenya's education system. Evidently, [1-3] indicate that entrepreneurship is the preferred bridge in reducing the gap between the current and desired levels in economic growth. [4] Observed that self-employment intentions are low among TVET graduates in developing countries like Kenya. According to the study [5] this is partly due to the poor entrepreneurial culture among the youth given that very few engage in self-employment after graduation. According to the Kenya Youth Empowerment Project (KYEP) 2014, youth unemployment is twice the national average of 40 percent.

Given the persistent unemployment problem among the Kenyan youth, most recently, the government through the sessional paper No 1 of 2015 on Reforming Education and Training re-emphasized the need for TVET Institutions concentrate on courses which are more skewed towards selfemployment.

The essence of self-employment is new venture creation, while opportunity identification is the very first step in entrepreneurship. Studies provide evidence that much of 'entrepreneurial' activity is intentionally planned behaviour. Entrepreneurial intention has been empirically proved to be the best and unbiased predictor of entrepreneurial behaviour or self-employment [5]. Since a common definition of selfemployment intention is lacking, it is incumbent upon researchers to define explicitly the meaning they ascribe to the term. For example, a study [6] defines entrepreneurial intention as the desire to be self-employed and starting one's own business. For the purpose this study, self-employment intention is defined as student's decisions about the likelihood of becoming self-employed at some point in time after graduation.

To investigate the combined effect of personality traits and cognitive factors on self-employment intentions among TVET students in Kenya, the study applied two theories. The theory of planned behaviour (TPB) and the personality traits theory both operationalized as cognitive factors (personal attraction towards self-employment and perceived social valuation) and personality factors (need for accomplishment and internal locus of control) deemed important in shaping and influencing a person's self-employment intentions.

\subsection{Statement of the Problem}

The youth unemployment rate worldwide continues to rise in recent years [7]. The report from Kenya's Economic Survey [8] indicates that less than percent of the students who graduate from both universities and TVET institutions are absorbed into formal employment annually. The rest are left out to compete for opportunities in the informal sector or simply waste away in idleness.

However, despite the government's effort to address the youth unemployment problems through job creation and initiatives to encourage them to venture into self-employment activities, more of those who graduate prefer formal career options as opposed to self-employment [7]. The opportunity costs and losses arising from unemployed and underemployed young therefore have and will continue to exert, tremendous impacts on society if these problems are not addressed in time. This observation is alarming and calls for an investigation of factors that influence the decision to be self-employed.

While there has been significant previous research on the causes and effects of self-employment there is a lack of rigour in past research studies regarding the combined effect of personality factors and cognitive factors on selfemployment intentions. Hence the need to investigate the combined effect of personality factors and cognitive factors on self-employment intentions among TVET students in Kenya.

\subsection{The Objective of the Study}

The objective of the study is to:

Establish the combined effect of personality factors and cognitive factors on students' self-employment intentions.

\subsection{Research Hypotheses}

$\mathrm{H}_{\mathrm{o} 1}$ : There is no significant combined effect on the relationship between personality factors and cognitive factors on students' self- employment intentions.

\subsection{Conceptual Framework}

The conceptual framework (figure 1) provides an overview of the relationships between independent variables and dependent variable. The conceptual model for the study is 
derived from the Theory of Planned Behaviour (TPB), operationalized cognitive factors comprising two elements; personal attraction towards self-employment, perceived social valuation and also extends the model to personality traits, as personality factors comprising two elements; need for accomplishment and internal locus of control. Both composite variables explain their relationship with selfemployment intentions among TVET students in Kenya.

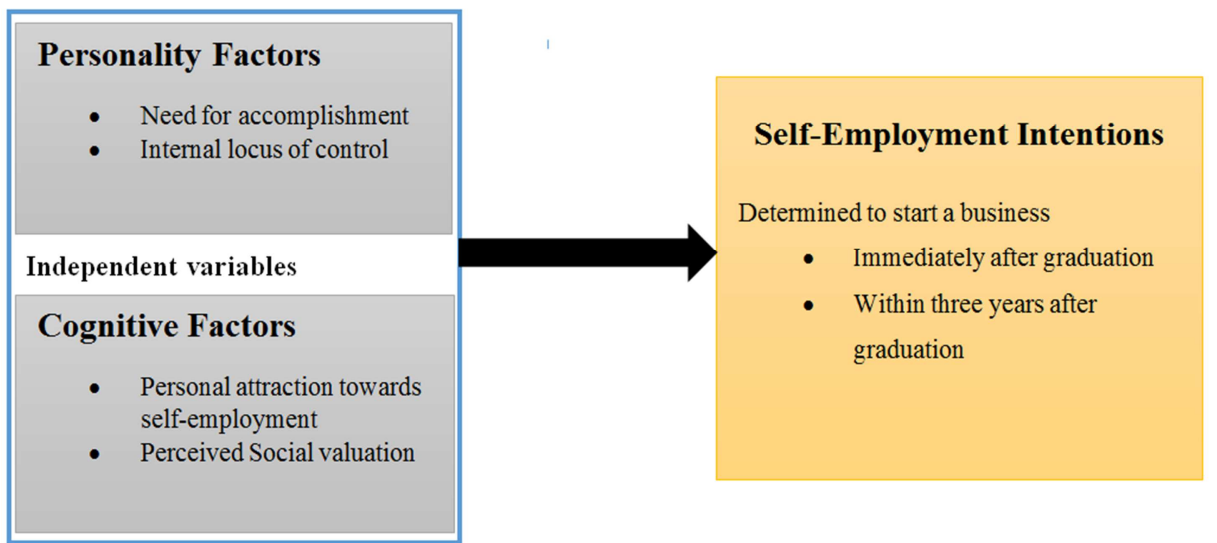

Independent Variables

Dependent Variable

Figure 1. Conceptual Framework.

\section{Literature Review}

\subsection{The Personality Factors and Self-Employment Intention}

Personality traits or psychological characteristics is another field of research that focuses on entrepreneurial intention [9]. The main assumption of this approach is that people who choose self-employment as a career option have peculiar personality profiles [10]. Personality traits are predictable characteristics of individual behaviour which assist in explaining the differences of individual actions in similar situations [11]. The characteristics inherent within personality traits include desire for achievement [12]; Locus of control [13]; risk taking propensity [14]; pro-activeness [15] and creativity [16]. These characteristics have become the focus of many researchers in the recent time. Youth often have a special personality. They value the issues of strength, autonomy and independence as important in their desire to become entrepreneurial [17].

This study focused on two main personality traits. They comprise; desire for achievement [12] and internal Locus of control [13]. For the purpose of this study, the two main personality traits were adopted as personality factors (need for accomplishment, internal locus of control) and reviewed to investigate how they influence self-employment intentions among TVET students in Kenya. [18] Used the same traits in their meta-analysis of the effect of personality on entrepreneurship. Similar Characteristics are preferred as most significant by these studies [19,9]. Alike, the study [19] linked psychological characteristics with self-employment intention and puts forward trait model that includes: need for achievement, internal locus of control. Personality factors (need for accomplishment, internal locus of control) are reviewed and discussed in the section that follows

\subsubsection{Need for Accomplishment and Self-Employment Intentions}

The need for accomplishment was first identified as a personality trait by a study [12] in his first work on economic development. He proposed that achievement motivation is the key to entrepreneurial behaviour. Recent studies on the need for accomplishment have shown that it can evolve over time, especially by obtaining an advanced education. The theory of the need to achieve claims that individuals who have a strong need to achieve commonly find their way to self-employment and their success rate is higher than that of other entrepreneurs [19]. High achievers typically choose situations that are linked with responsibility, moderate risktaking, and knowledge of results of decisions, new instrumental activity and anticipation of possibilities in the future.

\subsubsection{Internal Locus of Control and Self-Employment Intentions}

Internal Locus of control $(L o C)$ is a personality variable that is related to the generalized expectations of a person on whether he/she will be able to control the events in life as an entrepreneur [20]. The LoC represents the degree to which individuals believe that their achievements are dependent on their own behaviour. Individuals with self-employment intention, consider that the accomplishment of the missions depends more on their own ability and actions (internal LoC), rather than luck or other people's efforts (external LoC) [21]. The empirical reports by [22-24], confirm that small businesses entrepreneurs are more oriented at the internal level than the population in general. To confirm the validity of internal locus of control in relation to self-employment intentions in a Kenyan context, this study therefore attempted to fill one of the gap by focusing on the relationship between personality factors (need for accomplishment, internal and 
self-employment intentions among TVET students in Kenya.

\subsection{The Cognitive Factors and Self-Employment Intentions}

The theory of planned behaviour (TPB) has been said to predict more on entrepreneurial intentions by considering not only personal characteristics but also social factors $[25-28,5]$. This model has been hailed for accurately predicting and explaining self-employment intentions in the past studies; [27-31, 25, 5]. TPB asserts that intentions are a function of three sets of factors: attitudes towards behaviour, subjective norms, and perceived behavioural control. in this study, two antecedents of intention are adopted as cognitive factors (personal attraction towards self-employment and perceived social valuation to assess the relationship between cognitive factors and students' self-employment intentions among TVET students in Kenya. Cognitive factors are characteristics that influence how people think and make decisions. Compared to personality, motives and core self-evaluation characteristics, cognitive factors tend to change overtime. The cognitive approach tries to develop an understanding of how people acquire and process information and utilize it to understand the world of entrepreneurship better [32]. They tend to be more heavily influenced by a person's perception of the situation he/she is involved in.

\subsubsection{Personal Attraction Towards Self-Employment and Self-Employment Intentions}

Personal attraction is the beliefs and perceptions regarding self-employment intentions and subsequent self-employment. [33] refer attitudes toward behaviour to the degree to which a person has a favourable evaluation appraisal of the level of being an entrepreneur, which is believed to have two components which work together; beliefs about consequences of becoming an entrepreneur (behavioural beliefs) and the corresponding positive or negative judgments about each of these features of the behaviour. Personal Attitude will either trigger a positive or negative intention of students [34].

\subsubsection{Perceived Social Valuation and Self-Employment Intentions}

Perceived social valuation is the individuals' entrepreneurial perceptions about the values, beliefs, and norms held by people whom they respect or regard as important (significant others) and the individuals' desire to comply with those norms [34]. The perceived social valuation has been used to investigate the effect of social pressures on the inclination to self-employment [33]. It is argued that social norms are less predictive of intentions for individuals who have a high internal locus of control [25] compared to those who have lower internal Locus of control.

\subsection{The Personality Factors, Cognitive Factors and Self-Employment Intentions}

The study focused on students' self-employment intentions at an early age between 18 and 26 years who are admitted to vocational institutions direct after secondary education at a time when they face critical decisions about programs to study for an intended career. similar studies; [3, 5-6], established that students who study between 24 and 34 years, are able to understand the factors that affect the intentions of a country's future entrepreneurs and are then most likely to start a business. To test whether there is a significant combined effect on the relationship between personality factors and cognitive factors on students' self- employment intentions; an integrated conceptual model for this research is developed (Figure 1). The model attempted to answer the question; "Does the combined effect of personality factors and cognitive factors have influence in students' intentions to start a new business?" Review of the literature discloses that most researchers focus on individual factors. This study therefore endeavours to research on combined effect on the relationship between personality traits and cognitive factors on students' self- employment intentions and improve on the existing literature.

\section{Methodology}

The study used a cross-sectional survey design with mixed approaches. A mixed method research uses a systematic integration of quantitative and qualitative methods in a single study for purposes of obtaining a fuller and deeper understanding of a phenomenon. The study population consisted of all diploma finalist students in the field of engineering in their final term. The engineering courses are classified into building construction, civil, electrical and electronic, mechanical and automobile. To select the sample size for the study, three stages were involved. Finally, based on Slovin's formula for determining the proportionate sample size of students in the 10 institutions, 397 respondents were selected for the study. The study used a questionnaire to collect primary data from the respondents. The secondary data was accessed from the findings stated in published documents and literatures related to research problem while the primary data was collected from respondents. The statistical processes in the analyses of the data comprised of descriptive statistics, ANOVA and inferential statistics. In order to assess the existence of relationship between the dimensions of personality factors and cognitive factors and self-employment intention, the Pearson's correlation coefficient ' $r$ ' was computed. In addition, multiple regression analysis was conducted to examine the relationships between independent variables and the dependent variable. A general equation of the multiple regression models is given as:

$$
\mathrm{Y}_{1}=\beta_{\mathrm{o} 1}+\beta_{1} \mathrm{PF}+\beta_{2} \mathrm{CF}+\varepsilon_{\mathrm{o}}
$$

Where: $\mathrm{Y}$ is the self-employment intention (SEI); $\beta_{0}$ is the intercept term; $\beta_{\mathrm{i}}(\mathrm{i}=1$ and 2$)$ are the regression coefficients; $\mathrm{PF}$ is Personality factors; $\mathrm{CF}$ is cognitive factors; and $\varepsilon$ is the random error term.

\section{Results/Findings}

Among the targeted 400 respondents, 397 respondents were issued with the questionnaire after which, 377 managed 
to fill and return them, thus yielding a response rate of $98.4 \%$. Among the respondents were 84 females constituting $22.3 \%$ of the sample and male constituted $77.7 \%$ of the sample. Age Distribution of Students in Selected TVET Institutions. In addition, majority of students (89.7\%) in TVET institutions age ranged from 19 to 24 years only $10.3 \%$ of students were aged above 25 years. The results suggest that the optimal age in learning TVET Institutions was within 25 years.

The objective of this study was to determine the combined effect of personality factors (need for accomplishment and internal locus of control) and cognitive factors (personal attraction towards self-employment and perceived social valuation) on self-employment intentions among TVET students in Kenya. In addition, this objective related to the testing of null hypothesis that stated: There is no significant combined effect on the relationship between personality factors and cognitive factors on students' self- employment intentions.

\subsection{Personality Factors}

The personality factors comprised two elements, the need for accomplishment and internal locus of control.

\subsubsection{Need for Accomplishment}

In order to test the factors effect of the 10 items of need for accomplishment under investigation, factor analysis was undertaken. In order to improve the interpretability of factors, varimax rotation was performed on the extracted component matrix. Two components were extracted. The two new components are described in Table 1.

Table 1. Need for Accomplishment Total Variance Explained by extracted factors.

\begin{tabular}{|c|c|c|c|c|c|c|}
\hline \multirow{2}{*}{ Component } & \multicolumn{3}{|c|}{ Initial Eigenvalues } & \multicolumn{3}{|c|}{ Rotation Sums of Squared Loadings } \\
\hline & Total & $\%$ of Variance & Cumulative\% & Total & $\%$ of Variance & Cumulative\% \\
\hline 1 & 5.607 & 50.975 & 50.975 & 5.040 & 45.822 & 45.822 \\
\hline 2 & 4.415 & 40.132 & 91.107 & 4.981 & 45.285 & 91.107 \\
\hline 3 & .978 & 8.893 & 100.000 & & & \\
\hline
\end{tabular}

According to the Table 1, two components are extracted. The first component involves setting and meeting standards of accomplishment. This factor is largely influenced by internal drive for action. The first need for accomplishment factor was labelled 'Intrinsic Motivation' and comprises personality factors such as one's aim to make successful achievements, enriching personal record of achievement, seeking happiness when successful at work, taking own risk for own achievement and feeling as a self-starter who is driven by strong desire to compete, pursue and attain challenging goals. The second component involves pressure exerted by the expectation of others. The second need for accomplishment factor was therefore labelled 'Extrinsic Motivation' and comprises quest for achievement, need for performance feedback, the desire to do the best in any work situations, desire to be successful in doing things differently and establishing own business termed as self and personal major goal.

\subsubsection{The Internal locus of Control}

Seven items, on five-point Likert scale type questions measured the internal locus of control constructs. Three new factors are extracted namely 'Capability Component', 'Hard work Component' and Action Component'.

Table 2. Internal Locus of Control Total Variance Explained by the Extracted Factors.

\begin{tabular}{llllll}
\hline \multirow{2}{*}{ Component } & \multicolumn{2}{l}{ Initial Eigenvalues } & \multicolumn{3}{l}{ Rotation Sums of Squared Loadings } \\
\cline { 2 - 6 } & Total & \% of Variance & Cumulative\% & Total & \% of Variance \\
\hline 1 & 3.076 & 43.949 & 43.949 & 2.999 & 42.840 \\
2 & 2.174 & 31.051 & 74.999 & 2.001 & 28.586 \\
3 & 1.750 & 25.001 & 100.000 & 2.000 & 28.574 \\
4 & 0.00 & .000 & 100.000 & & \\
\hline
\end{tabular}

The first component factor loading was labelled 'Capability Component'. Three items that loaded on this variable included statement that measured the extent to which one's leadership depends on individual ability, preference of work depends on original thinking and original idea is independent on time of the day. The second component factor loading was labelled 'Hard Work Component'. Two items that loaded on this component measured the degree to an individual accomplishment and setbacks are within his/her control and may affect the outcome of self-employment and whether any outcome of an activity is due to hard work. The final component was renamed 'Action Component' variable. Two items that loaded on these variable included statements that measured the extent to which ones feeling determines future outcome and whether one's life may determine own action as an entrepreneur.

\subsection{Cognitive Factors}

The cognitive factors comprised two elements, the personal attraction towards self-employment and perceived social valuation.

\subsubsection{Personal Attraction Towards Self-Employment}

Ten items in the structured questionnaire were used to measure Personal Attraction towards self-employment variables of cognitive factors. Factor analysis produced three components accounting for 82.273 percent of the total variance of the 10 items of personal attraction. 
Table 3. Personal Attraction Total Variance Explained by Extracted Factors.

\begin{tabular}{lllllll}
\hline \multirow{2}{*}{ Component } & \multicolumn{2}{l}{ Initial Eigenvalues } & & \multicolumn{3}{l}{ Rotation Sums of Squared Loadings } \\
\cline { 2 - 7 } & Total & \% of Variance & Cumulative\% & Total & \% of Variance & Cumulative\% \\
\hline 1 & 5.053 & 50.528 & 50.528 & 5.027 & 50.274 & 50.274 \\
2 & 2.010 & 20.101 & 70.629 & 2.031 & 20.306 & 70.579 \\
3 & 1.364 & 13.645 & 84.273 & 1.369 & 13.694 & 84.273 \\
4 & .941 & 9.407 & 93.680 & & & \\
5 & .632 & 6.320 & 100.000 & & & \\
\hline
\end{tabular}

The three components are 'Satisfaction component', 'Success component' and 'Evaluation component'. The first component was labelled 'Satisfaction component' includes statement that measure the degree to which self-employment is considered as an alternative career to people armed with technical education, writing a business plan is a motivator towards starting own business, self-employment is preferred although faced with many challenges, being an entrepreneur is very attractive and satisfying to those involved. 'Success variable' corresponds to statements that measured the extent to which entrepreneurship education course has re- engineered students' quest for self-employment and also the degree to which students are able to make significant personal sacrifices in order to stay in business. The third component factor loading corresponds to 'Evaluation Component with items required that students respond to the allegations that technical courses have not contributed positively to student graduates becoming self-employed and that being self-employed implies more disadvantages than advantages to students. Nine items were used to measure perceived social valuation of cognitive factor. Factor analysis produced three components.

Table 4. Perceived Social Valuation Total Variance Explained by Extracted Factors.

\begin{tabular}{llllll}
\hline \multirow{2}{*}{ Component } & \multicolumn{2}{l}{ Initial Eigenvalues } & & \multicolumn{2}{c}{ Rotation Sums of Squared Loadings } \\
\cline { 2 - 6 } & Total & \% of Variance & Cumulative\% & Total & \% of Variance \\
\hline 1 & 3.459 & 34.586 & 34.586 & 2.870 & 28.704 \\
2 & 1.953 & 19.526 & 54.112 & 2.194 & 21.940 \\
3 & 1.144 & 11.436 & 65.548 & 1.490 & 14.904 \\
4 & .956 & 9.564 & 75.112 & & \\
5 & .740 & 7.399 & 82.511 & & \\
6 & .583 & 5.834 & 88.345 & & \\
\hline
\end{tabular}

\subsubsection{Perceived Social Valuation}

The three components are 'Mentor component', 'Value Component' and Significant Other Component'. Four items that loaded to Mentor component' included statements that measured the extent to which parents and other successful entrepreneurs have acted as role models in inculcating selfemployment intentions to students; family business has increased desire for children to enhance their desire for selfemployment; the role of other entrepreneurs in the community to mentor students on self-employment after graduation; and the general opinion of a family of one becoming self-employed is very important. The second component was re-named 'Value Component' included statements that measured the degree to which the immediate family was willing to add value by providing financial support to students so as enhance their self-employment intention, how culture relate with entrepreneurial activities and how the opinion of others was important in influencing students to become self-employed. The third component factor loadings corresponded to 'Significant other Component' variable. Two items that loaded to these variable included statements that measured the extent to which TVET institutions regard the construct of self-employment despite the high risk involved and the extent to which significant others encourage students to become entrepreneurs after college life.

The multiple regression models of the eleven components assumed the form:

$$
\begin{gathered}
\mathrm{Y}=\beta_{\mathrm{o}}+\beta_{1} \mathrm{X}_{\mathrm{IM}}+\beta_{2} \mathrm{X}_{\mathrm{EM}^{+}} \beta_{1} \mathrm{X}_{\mathrm{C}}+\beta_{2} \mathrm{X}_{\mathrm{H}}+\beta_{1} \mathrm{X}_{\mathrm{A}}+\beta_{1} \mathrm{X}_{\mathrm{S}}+\beta_{1} \mathrm{X}_{\mathrm{SS}^{+}} \\
\beta_{2} \mathrm{X}_{\mathrm{E}}+\beta_{2} \mathrm{X}_{\mathrm{M}}+\beta_{2} \mathrm{X}_{\mathrm{V}}+\beta_{1} \mathrm{X}_{\mathrm{SO}}+\varepsilon_{\mathrm{o}}
\end{gathered}
$$

$\mathrm{Y}=$ Self-Employment Intention, $\mathrm{X}_{\mathrm{IM}}=$ Intrinsic Motivation Component

$\mathrm{X}_{\mathrm{EM}}=$ Extrinsic Motivation Component, $\mathrm{X}_{\mathrm{C}}=$ Capability Component, $\mathrm{X}_{\mathrm{H}}=$ Hard work Component, $\mathrm{X}_{\mathrm{A}}=$ Action Component, $\mathrm{X}_{\mathrm{S}}=$ Satisfaction component, $\mathrm{X}_{\mathrm{SS}}=$ Success component, $\mathrm{X}_{\mathrm{E}}=$ Evaluation component, $\mathrm{X}_{\mathrm{M}}=$ Mentor component, $\mathrm{X}_{\mathrm{V}}=$ Value Component, $\mathrm{X}_{\mathrm{SO}}=$ Significant other Component. Multiple Regressions was used to test the null hypothesis that was stated:

$H_{o} 1$ : There is no significant combined effect on the relationship between personality factors and cognitive factors on students' self-employment intentions.

The multiple regression models were summarized as:

Self-Employment Intention $=12.24+.534 \mathrm{X}_{\mathrm{IM}^{+}}+.483$ $\mathrm{X}_{\mathrm{EM}}+.516 \mathrm{X}_{\mathrm{C}}+.460 \mathrm{X}_{\mathrm{H}}+.386 \mathrm{X}_{\mathrm{A}}+.652 \mathrm{X}_{\mathrm{S}}++.586 \mathrm{X}_{\mathrm{SS}}+.433$ $\mathrm{X}_{\mathrm{E}}+.350 \mathrm{X}_{\mathrm{M}}+.264 \quad \mathrm{X}_{\mathrm{V}}+0.579 \quad \mathrm{X}_{\mathrm{SO}}$. These results are summarized in Table 5. 
Table 5. Regression Analysis of the Combined Effect of Personality Traits and Cognitive Factors on Self-Employment Intention.

\begin{tabular}{|c|c|c|c|c|c|}
\hline & \multicolumn{2}{|c|}{ Un standardized Coefficients } & \multirow{2}{*}{$\begin{array}{l}\text { Standardized Coefficients } \\
\text { Beta }\end{array}$} & \multirow{2}{*}{$\mathbf{T}$} & \multirow{2}{*}{ Sig. } \\
\hline & B & Std. Error & & & \\
\hline (Constant) & 11.24 & .528 & & 23.2 & .000 \\
\hline Intrinsic Motivation & .534 & .018 & .579 & 34.9 & .000 \\
\hline Extrinsic Motivation & .483 & .019 & .685 & 41.2 & .000 \\
\hline Capability Component & .516 & .232 & .409 & .515 & .000 \\
\hline Hard Work Component & .460 & .048 & .686 & 41.0 & .000 \\
\hline Acton Component & .386 & .045 & .579 & 34.8 & .000 \\
\hline Satisfaction Component & .652 & .416 & .685 & 41.2 & .000 \\
\hline Success Component & .586 & .450 & .579 & 34.8 & .000 \\
\hline Evaluation Component & .433 & .580 & .329 & .557 & .000 \\
\hline Mentor Component & .350 & .084 & .240 & 4.14 & .000 \\
\hline Value Component & .264 & .165 & .092 & 1.60 & .110 \\
\hline Significant other component & .579 & .119 & .575 & 13.2 & .000 \\
\hline
\end{tabular}

From the analysis of variance, the results are significant at.05 levels. This implies that there was a significant relationship between the combined effect variables of personality traits and cognitive factors and self-employment intention. The study thus concluded that the eleven components namely; Intrinsic Motivation, Extrinsic Motivation, Capability Component, Hard Work Component, Acton Component, Satisfaction Component, Success Component, Evaluation Component, Mentor Component, Value Component and Significant other component all have a positive effect on self-employment intention.

The null hypothesis that there was no significant combined effect on the relationship between personality factors and cognitive factors on students' self-employment intentions among students in TVET institutions in Kenya was rejected.

\section{Discussion}

Both personality factors and cognitive factors have jointly been found to be a significant predictor of self-employment intentions. The independent variables of this study are personality factors and cognitive factors. These factors were individually correlated with self-employment as the dependent variable. Results of correlation analysis between all the dependent variables and self-employment showed positive and significant results at.05 significant levels. This shows that self-employment intention among student are dependent upon ones need of achievement, one's internal locus of control, personal attraction towards self-employment and perceived social valuation.

To study further on the internal structure of the factors defining personality factors and cognitive factors, eleven more factors were included in the model. These are: intrinsic motivation, extrinsic motivation, capability component, hard work component, action component, satisfaction component, success component, evaluation component, mentor component, value component and significant other component, all have a positive effect on self-employment intention. The first component involves setting and meeting standards of accomplishment. These results indicate that intrinsic motivation is an important ingredient for need for accomplishment and consequently an important factor in student's self-employment intention. [8] Suggest that need for achievement should be higher in people who have the urge to start a business. The second component involves pressure exerted by the expectation of others. The results show that expectations of others for one's accomplishment drive students into self- employment intentions after college life. The third component show that capability influence of a student in TVET institution do affect self-employment intentions [6]. The fourth component indicates that indicate that one of the key factors in self-employment intention among students in TVET institutions is individual hard work. People believe that their hard work would lead them to obtain positive outcomes.

The six personality factors correspond to Action variable which explained the extent to which ones feeling determines future outcome and whether one's life may determine own action as an entrepreneur. These results observed that people with external locus of control tend to believe that the things which happen in their lives are out of their control. The first three factors defining personal attraction factors are Satisfaction component, Success component and Evaluation component. These results show that the selected number of students for this study would largely have positive attitude towards self-employment after completing their study at TVET institutions.

These findings are congruent with previous studies [9-12], who have positively associated personal attitude to intention. Factors that explain Perceived Social Valuation; Mentor component, Value Component and Significant Other Component. The results indicated that decision by students to become self-employed after graduation entirely depends on mentorship process from parents and other successful entrepreneurs in the community. In addition, results show that students' self-employment intention is cultivated through the value added to them by family members and those close to them. Finally, students' self-employment intention is enhanced through significant other such as family members and TVET institutions themselves. The research findings indicate that individuals are more likely to start a business when they have relationships with others who are entrepreneurs. 


\section{Conclusion}

Based on the findings, the two independent variables (personality factors and cognitive factors) were found to be jointly associated with self-employment intention among engineering students in TVET institutions in Kenya. This study concluded that although personality factors and cognitive factors positively individually influenced selfemployment intention, their combined association enhanced their effect further. This research makes a contribution to literature by introducing a new regression model on the joint effect between personality factors and cognitive factors on self-employment intention among engineering students in TVET institutions. A review of the existing literature discloses that there are several models explaining the nature, antecedents, and effects of Self-employment intentions. However, investigations by the researcher could not find any study that focused on combined effect of personality factors and cognitive factors on self- employment intentions. Nevertheless, the study introduced the following new model as a measure of filling this research gap: Self-Employment Intention $=12.24+.534 \mathrm{X}_{\mathrm{IM}}+.483 \mathrm{X}_{\mathrm{EM}}+.516 \mathrm{X}_{\mathrm{C}}+.460$ $\mathrm{X}_{\mathrm{H}}+.386 \mathrm{X}_{\mathrm{A}}+.652 \mathrm{X}_{\mathrm{S}}+.586 \mathrm{X}_{\mathrm{SS}}+.433 \mathrm{X}_{\mathrm{E}}+.350 \mathrm{X}_{\mathrm{M}}$ $+.264 \mathrm{X}_{\mathrm{V}}+0.579 \mathrm{X}_{\mathrm{SO}}$. Where, $\mathrm{XEM}=$ Extrinsic Motivation Component, $\mathrm{X}_{\mathrm{C}}=$ Capability Component, $\mathrm{X}_{\mathrm{H}}=$ Hard work Component, $\mathrm{X}_{\mathrm{A}}=$ Action Component, $\mathrm{X}_{\mathrm{S}}=$ Satisfaction component, $\mathrm{X}_{\mathrm{SS}}=$ Success component, $\mathrm{X}_{\mathrm{E}}=$ Evaluation component, $\mathrm{X}_{\mathrm{M}}=$ Mentor component, $\mathrm{X}_{\mathrm{V}}=$ Value Component, $\mathrm{X}_{\mathrm{SO}}=$ Significant other Component.

\section{References}

[1] K. King and R. Palmer, "Planning for Technical and Vocational Skills Development," International Institute for Educational Planning, 2010.

[2] R. McGrath, "Entrepreneurship, Small Firms and Wealth Creation: A Framework Using Real Options Reasoning," in Handbook of Strategy and Management, 2002, pp. 299-325.

[3] D. Turker and S. Selçuk, "Which factors affect entrepreneurial intention of university students?," Journal of European Industrial Training, pp. 142-159, 2009.

[4] H. Haase, A. Lautenschläger and R. Rena, "The entrepreneurial mind-set of university students: a crosscultural comparison between Namibia and Germany," International Journal of Education Economics and Development, vol. 2, no. 2, pp. 113-129, 2011.

[5] J. Moriano, M. Gorgievski, M. Laguna, U. Stephan and K. Zarafshani, "A cross cultural approach to understanding entrepreneurial intention," Journal of Career Development, vol. 39, no. 2, pp. 162-185, 2012.

[6] H. Zhao, S. Seibert, \& G. Hills, "The mediating role of selfefficacy in the development of entrepreneurial intentions". Journal of applied psychology, 90(6), 2005.

[7] E. J. Douglas, "Reconstructing entrepreneurial intentions to identify predisposition for growth," Journal of Business Venturing, vol. 28, pp. 633-651, 2013.
[8] ILO, "World employment social outlook: Trend for youth 2016," Geneva, 2016.

[9] G. Gurbuz and S. Aykol, "Entrepreneurial intentions of young educated public in Turkey," Journal of Global Strategic Management, pp. 47-56, 2008.

[10] L. Kolvereid, Prediction of employment status choice intentions: Entrepreneurship Theory \& Practice, vol. 21, 1996, pp. 47-57.

[11] D. J. Llewellyn and K. M. Wilson, "The controversial role of personality traits in entrepreneurial psychology.," Education+ Training, pp. 341-345, 2003.

[12] D. C. McClelland, The Achieving Society, Free Press Paperback, 1961.

[13] P. B. Robinson, D. V. Stimpson, J. C. Huefner and H. K. Hunt, "An attitude approach to the prediction of entrepreneurship.," Entrepreneurship theory and practice, pp. 13-31, 1991.

[14] R. Brockhaus, "Risk Taking Propensity of Entrepreneurs," Academy of Management Journal, vol. 23, no. 3, pp. 509-520, 1980.

[15] D. Miller, "The correlates of entrepreneurship in three types of firms," Management science, vol. 29, no. 7, pp. 770-791, 1983.

[16] P. F. Drucker, "Entrepreneurial strategies.," California Management Review, vol. 27, no. 2, pp. 9-25., 1985.

[17] N. Bhandari, "Intention for Entrepreneurship among students in India," The journal of. Entrepreneurship, vol. 15, no. 2, p. 169-179, 2006.

[18] A. Rauch and M. Frese, "Born to be an entrepreneur? Revisiting the personality approach to entrepreneurship," The psychology of entrepreneurship, pp. 41-65, 2007.

[19] H. Littunen, "Entrepreneurship and the characteristics of the entrepreneurial personality," International Journal of Entrepreneurial Behavior \& Research, vol. 6, no. 6, pp. 295$310,2000$.

[20] C. Leone and J. Burns, "The measurement of locus of control: assessing more than meets the eye?," The Journal of Psychology, pp. 63-76, 2000.

[21] D. F. Kuratko and R. M. Hodgetts, 'Entrepreneurship: Theory, Process and Practice', 8th edn., Ohio: Thomson Learning, Ohio, US., 2009.

[22] M. F. R. De Vries, "The entrepreneurial personality: A person at the crossroads.," Journal of management studies, vol. 14, no. 1, pp. 34-57., 1977.

[23] T. M. Begley and D. P. Boyd, "Psychological characteristics associated with performence in entrepreneurial firms and smaller businesses.," Journal of business venturing, vol. 2, no. 1, pp. 79-93., 1987.

[24] I. Lückgen, D. Oberschachtsiek, R. Sternberg and J. Wagner, "Nascent Entrepreneurs in German Regions: Evidence from the Regional Entrepreneurship Monitor (REM)," IZA Discussion Paper No. 1394, 2004.

[25] N. J. Krueger, M. Reilly and A. Carsrud, "“Competing models of entrepreneurial intentions"," Journal of Business Venturing, 2000 .

[26] E. Autio, R. H. Keeley, M. Klofsten, G. G. Parker and M. Hay, "Entrepreneurial intent among students in Scandinavia and in the USA," Enterprise and Innovation Management Studies, vol. 2, no. 2, pp. 145-160, 2001. 
[27] V. Souitaris, S. Zerbinati and A. Al-Laham, "Do Entrepreneurship Programmes Raise Entrepreneurial Intention of Science and Engineering Students? The Effect of Learning, Inspiration and Resources," Journal of Business Venturing, vol. 22, no. 4, pp. 566-591, 2007.

[28] R. L. Engle, N. Dimitriadi, J. E. Gavidia, C. Schlaegel, S. Delanoe, I. H. X. Alvarado, S. Buame and B. (. Wolff, "Entrepreneurial intent: A twelve-country evaluation of Ajzen's model of planned behaviour," International Journal of Entrepreneurial Behaviour \& Research, vol. 16, no. 1, pp. 35-57, 2010.

[29] M. Gelderen Van, M. Brand, M. van Praag, W. Bodewes, E. Poutsma and A. Van Gils, "Explaining entrepreneurial intentions by means of the theory of planned behaviour.," Career Development International, pp. 538-559, 2008.

[30] A. Gird and J. Bagraim, "The theory of planned behaviour as predictor of entrepreneurial intent amongst final-year university students.," South Africa Journal of Psychology, pp. 711-724, 2008.

[31] M. Ariff, A. H. a. Bidin, Z. a. Sharif, Z. a. Ahmad and Adura, "Predicting entrepreneurship intention among Malay university accounting students in Malaysia," Universiti Tun Abdul Razak e-Journal,, vol. 6, no. 1, pp. 1-10, 2010.

[32] F. Wilson, J. Kickul and D. Marlino, "Gender, entrepreneurial Self-Efficacy, and entrepreneurial career intentions: Implications for entrepreneurship Education1," Entrepreneurship theory and practice, pp. 387-406, 2007.

[33] F. Liñán and Y. Chen, "Development and Cross-Cultural application of a specific instrument to measure entrepreneurial intentions," Entrepreneurship theory and practice, vol. 33, no. 3, pp. 593-617, 2009.

[34] I. Ajzen, "Nature and operation of attitudes," Annual review of psychology, vol. 52, no. 1, pp. 27-58, 2001. 